\title{
Prevalence of Residual B-Cell Function in Insulin-Treated Diabetics Evaluated by the Plasma C-Peptide Response to Intravenous Glucagon
}

\author{
C. Hendriksen, O. K. Faber ${ }^{1}$, J. Drejer, and C. Binder \\ Hvidøre Hospital, Klampenborg, Denmark
}

Summary. In 83 insulin-treated diabetics the influence of the duration of insulin treatment on the prevalence of residual insulin secretion was examined by determining the plasma $\mathrm{C}$-peptide concentration before and after intravenous injection of $1 \mathrm{mg}$ of glucagon. In 64 patients, plasma C-peptide concentration was also determined before and after a standard meal. There was a good correlation between the C-peptide response to glucagon and to the meal $(r=0.67 ; p<0.0001)$ suggesting that the glucagon test will predict the B-cell response during everyday life. The predictive value of a positive glucagon test was $84 \%$ and of a negative test $100 \%$. A preserved, but reduced, B-cell function was demonstrable in 36 of 83 patients. Residual B-cell function was most frequent in the patients with the shortest duration of diabetes. The metabolic importance of endogenous insulin was demonstrated by the significantly lower insulin requirement in the patients with residual B-cell function.

Key words: Insulin-treated diabetics, C-peptide, IV glucagon test, residual B-cell function.

Determination of the concentration of C-peptide in peripheral venous plasma yields an indirect, but specific, measure of the secretion of insulin from the B-cells of the islets of Langerhans [1, 2, 3]. C-peptide determinations are especially of value in subjects in whom exogenous insulin and circulating insulin antibodies interfere with quantitative measurements of endogenous insulin [1].

1 O.K. Faber is a Research Fellow at the University of Copenhagen
It has been demonstrated that, within the first year of treatment, most diabetics on insulin have a much reduced insulin secretion $[4,5,6]$ and that, following a temporary respite within the first 2-5 months, insulin secretion decreases with time [7].

Determination of the C-peptide concentration before and after stimulation with glucagon has been found to reflect quantitatively B-cell function under normal conditions of life in patients with insulin-dependent diabetes mellitus of short duration [8].

The aim of the present work was, by use of the glucagon test, to examine the influence of the duration of insulin treatment on the prevalence of residual B-cell function. The study also includes an evaluation of the discriminatory capacity of the test when applied to subjects with diabetes of long duration.

\section{Study Population and Methods}

The study population comprised 83 patients with insulin-treated diabetes mellitus. Duration of treatment was one to 50 years (mean 12) and age at onset 3 to 50 years (mean 22) (Fig. 1). Insulin treatment was started at the time of diagnosis in all but 7 patients. This subgroup had known diabetes for 1-8 years (mean 3 years) before insulin treatment was started. At the time of study, they had been insulin-treated for 1-4 years (mean 2 years). Their age at the time of diagnosis ranged from 27 to 48 years (mean 38 years). The insulin dose for the whole study population varied from 0.07 to 0.91 units $/ \mathrm{kg} / 24 \mathrm{~h}$ (mean 0.49). All patients were within $\pm 15 \%$ of their ideal body weight (9) except one woman (weight $77.6 \mathrm{~kg}$, height $166 \mathrm{~cm}$ ) with insulindependent diabetes since age 10 . In 11 patients, the serum creatinine exceeded $120 \mu \mathrm{mol} / 1$ and 3 had al- 


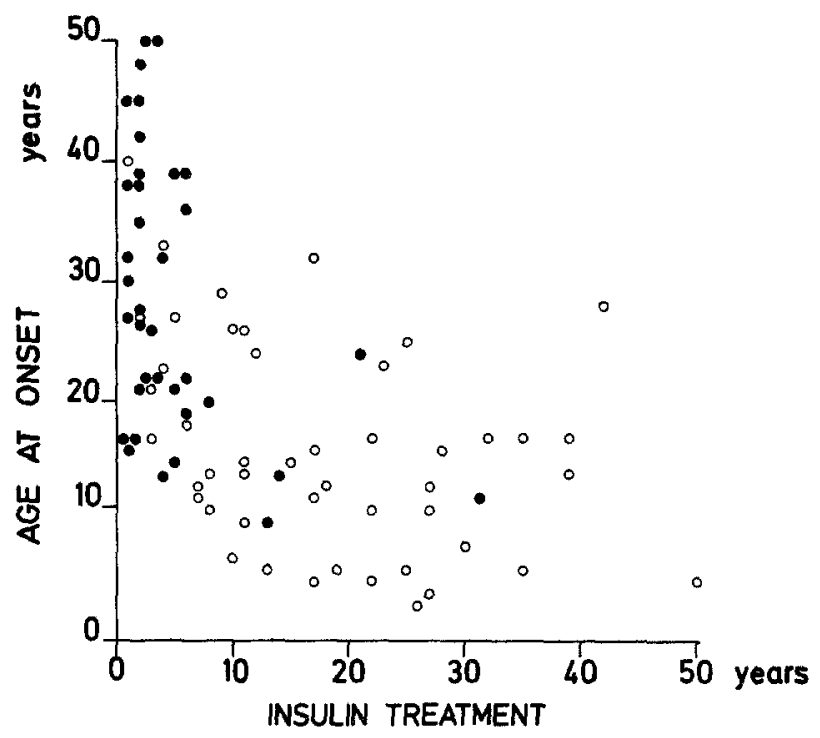

Fig. 1. Age at the time of diagnosis and duration of insulin treatment in 83 patients with insulin-treated diabetes mellitus. •, indicates subjects with and, $O$, subjects without a significant plasma C-peptide increase after $1 \mathrm{mg}$ of glucagon IV

buminuria. Two others had chronic albuminuria, but normal serum creatinine. All patients gave informed consent to the investigation.

They were tested after an overnight fast. Freeflowing venous blood was sampled 10,5 and $0 \mathrm{~min}$ before and 2, 4, 6, 8, 10, 15 and 20 min after an IV bolus of $1 \mathrm{mg}$ porcine glucagon (NOVO). Apart from mild nausea in some patients $1-4$ min after the injection, no side effects were observed during or after the administration of glucagon. For each sample, $7 \mathrm{ml}$ blood were transferred to a plastic tube with $700 \mu \mathrm{l}$ of a trasylol-heparin mixture (Trasylol Bayer $^{\circledR} 5000 \mathrm{KIE} / \mathrm{ml}$ and Heparin Novo ${ }^{\circledast} 5000$ $\mu \mathrm{U} / \mathrm{ml}$, relative proportions $10: 1$ ). The tubes were kept at room temperature until after the test when they were spun at $3000 \times \mathrm{g}$ for $10 \mathrm{~min}$ at $4^{\circ} \mathrm{C}$. The supernatant was pipetted into plastic tubes and immediately stored at $-20^{\circ} \mathrm{C}$. In 64 patients, venous blood was also sampled before and one hour after the start of a standard breakfast. The meal was composed of $34 \%$ fat, $45 \%$ carbohydrate, and $21 \%$ protein and amounted to $435 \mathrm{kCal}(1823 \mathrm{~kJ})$. The glucagon test and the meal test were carried out in random order with an interval of 3 to 7 days.

The plasma C-peptide concentration was measured as described by Heding [3], employing the antibody $\mathrm{M} 1230$ [10]. In this assay human proinsulin cross-reacts no more than $13 \%$ on a molar basis with C-peptide (unpublished observation). All samples from a given study were analyzed in the same assay. The intra-assay coefficient of variation in the low part of the working range of the $\mathrm{C}$-peptide assay was 5.4 per cent [10]. The "effective" detection limit of the C-peptide assay was $0.06 \mathrm{pmol} / \mathrm{ml}$. This limit was defined by the upper range of values measured in 10 pancreatectomized patients. The detection limit in the assay buffer was $0.02 \mathrm{pmol} / \mathrm{ml}$. A significant increase in the C-peptide concentration was defined as an increase exceeding $16.2 \%$ ( $3 \times$ within-assay coefficient of variation) of the individual fasting level provided that one of the values was greater or equal to $0.06 \mathrm{pmol} / \mathrm{ml}$. i. e., the "effective" detection limit.

The discriminatory capacity of the glucagon test as an indicator of B-cell function during everyday life was evaluated from the predictive values of positive and negative tests. The predictive value of a positive test was calculated as the number of true positives (those subjects who showed a significant C-peptide response to both stimuli) divided by the number of true positives plus the number of false positives (those subjects who showed a significant C-peptide response to glucagon but not to the meal). The predictive value of a negative test was calculated in a similar way as the number of true negatives divided by the number of true negatives plus the number of false negatives.

Blood glucose concentration was measured using a glucose-oxidase method.

The significance of correlation was tested by the Spearman rank correlation coefficient. The MannWhitney rank sum test for unpaired data was used for statistical evaluation of comparison between groups.

\section{Results}

Fasting blood glucose ranged between 3.6 and $22.1 \mathrm{mmol} / 1$ (mean 12.1) in the 83 patients before the glucagon test and between 4.4 and $21.7 \mathrm{mmol} / 1$ (mean 13.0) in the 64 patients on the day of the meal test. The increase in glucose $20 \mathrm{~min}$ after glucagon ranged from 0.6 to $5.8 \mathrm{mmol} / 1$ (mean 3.0 ) and that one hour after the meal from 1.4 to $10.9 \mathrm{mmol} / 1$ (mean 5.9 ).

The fasting C-peptide concentration in the 83 glucagon tested patients ranged from 0 to 0.39 $\mathrm{pmol} / \mathrm{ml}$. Following stimulation with glucagon, the maximum increase in C-peptide concentration, which occurred 4-6 min after the bolus injection, varied between 0 and $0.35 \mathrm{pmol} / \mathrm{ml}$. A significant increase was observed in 36 of the 83 patients. The fasting C-peptide concentration was positively correlated with the maximum increase following glucagon $(r=0.79 ; p<0.0001)$ in these patients. A significant increase in the plasma $\mathrm{C}$-peptide concentra- 


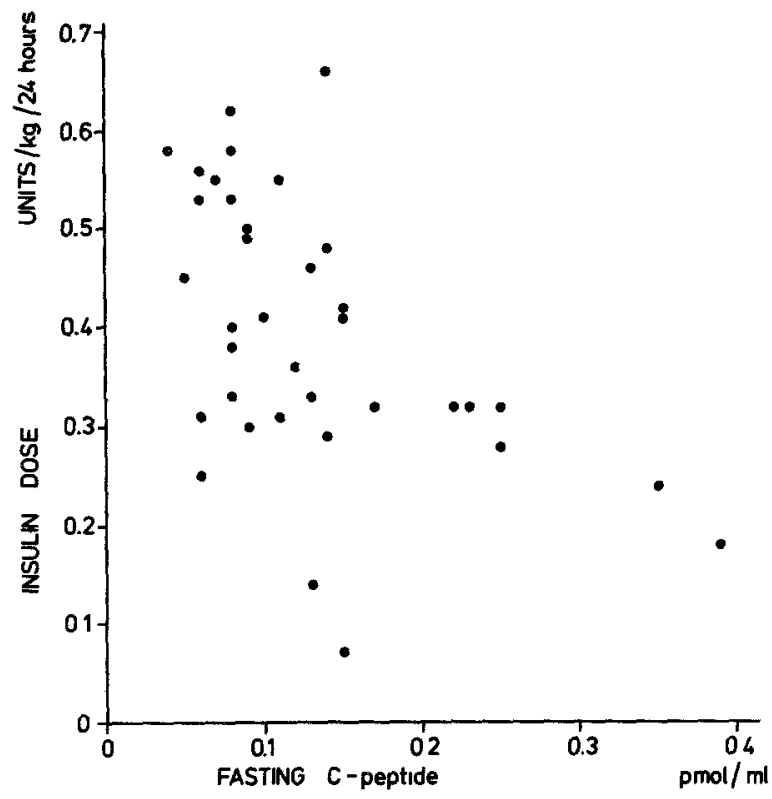

Fig. 2. The correlation between insulin dose and fasting $C$-peptide concentration. Results from 36 insulin-treated diabetics with a significant increase in the plasma $\mathrm{C}$-peptide concentration in response to glucagon $(\mathrm{r}=-0.51, \mathrm{p}<0.003)$

Table 1. Relation of C-peptide response to IV glucagon to fasting C-peptide concentration. See text for definition of response

\begin{tabular}{lll}
\hline $\begin{array}{l}\text { Fasting C-peptide } \\
\text { concentration } \\
\text { pmol/ml }\end{array}$ & Number of patients & $\begin{array}{l}\text { Number of patients } \\
\text { with response to } \\
\text { glucagon }\end{array}$ \\
\hline$\geqq 0.08$ & 29 & 29 \\
0.07 and 0.06 & 11 & 5 \\
0.05 and 0.04 & 23 & 2 \\
$\leqq 0.03$ & 20 & 0 \\
Total & 83 & 36 \\
\hline
\end{tabular}

tion was found in all patients with fasting C-peptide concentration $\geqq 0.08 \mathrm{pmol} / \mathrm{ml}$ and in 7 patients with fasting C-peptide concentrations $<0.08 \mathrm{pmol} / \mathrm{ml}$. There was no increase in the plasma C-peptide concentration in response to glucagon in patients with fasting C-peptide concentrations $\leqslant 0.03 \mathrm{pmol} / \mathrm{ml}$ (Table 1).

The C-peptide response to glucagon was significant in 31 of 39 patients ( 79 per cent) treated with insulin for one to 6 years and in 5 of 44 patients (11 per cent) treated for 7 to 50 years (Fig. 1).

In the patients with residual $\mathrm{B}$-cell function the insulin dose (mean 0.40 , range $0.07-0.66$ units $/ \mathrm{kg} /$ 24 hours) was found to be lower than in the patients with no B-cell function (mean 0.55, range $0.20-0.91$ units $/ \mathrm{kg} / 24$ hours) ( $\mathrm{p}<0.001)$. Average fasting

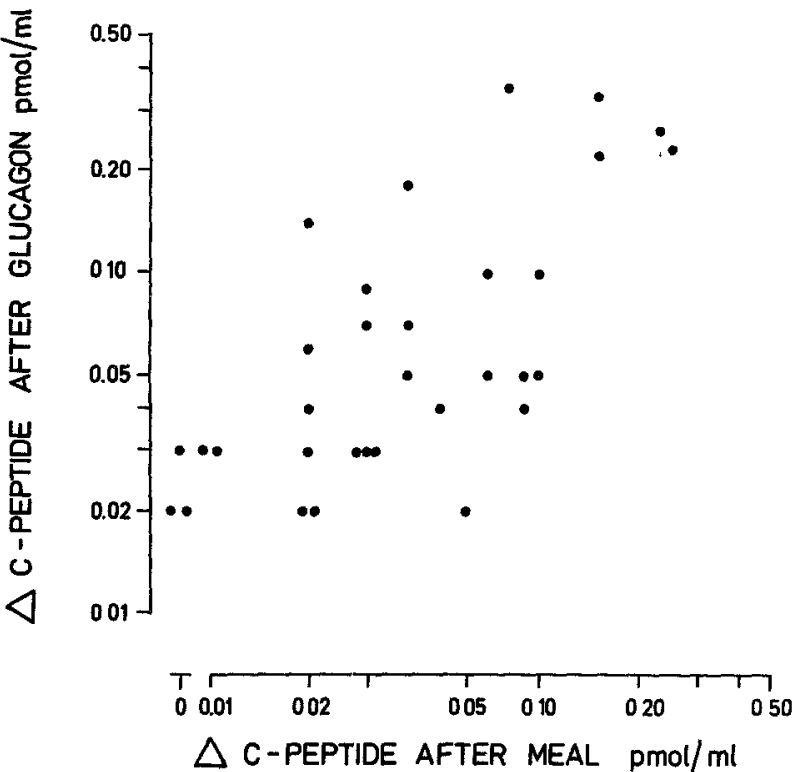

Fig. 3. The correlation between the increase in the plasma C-peptide concentration in response to $1 \mathrm{mg} \mathrm{IV}$ glucagon and in response to a standard meal. Results from 32 insulin-treated diabetics with a significant increase in the plasma C-peptide concentration in response to glucagon $(r=0.67, p<0.0001)$. Abscissa and ordinate plotted on a logarithmic scale

blood glucose concentration was 11.8 (range 5.7-22.1) $\mathrm{mmol} / 1$ in patients with residual B-cell function and 12.1 (range 3.7-21.4) $\mathrm{mmol} / \mathrm{l}$ in those without. The insulin dose was inversely correlated with the fasting $\mathrm{C}$-peptide concentration in patients with a residual $\mathrm{B}$-cell functions $(\mathrm{r}=-0.51$, $\mathrm{p}<0.003)$ in that the patients given the highest doses had the lowest fasting C-peptide concentrations (Fig. 2). The dose was also inversely correlated with the increase in $\mathrm{C}$-peptide concentration following glucagon $(r=-0.42 ; p<0.02)$. There was no correlation between the fasting blood glucose concentration and the increase in the C-peptide concentration in response to glucagon.

In the 64 patients in whom the glucagon as well as the meal stimulation tests were studied the increase in the C-peptide concentration varied from 0 to $0.35 \mathrm{pmol} / \mathrm{ml}$ following glucagon and from 0 to $0.25 \mathrm{pmol} / \mathrm{ml}$ following the meal. In 27 of the 64 patients both types of stimulation caused a significant increase in C-peptide concentration. In 5 patients there was a significant $\mathrm{C}$-peptide response to glucagon, but not to the meal. Of these 5 patients only one failed to show significant amounts of Cpeptide in the plasma. All patients who responded to the meal had a significant $\mathrm{C}$-peptide response to glucagon. In 32 patients there was neither a response to glucagon nor to the meal. The predictive 
value of a positive test was $27 /(27+5)=84.4 \%$ (95\% confidence limits $67.2-94.7 \%$ ) and of a negative test $32 /(32+0)=100 \%(95 \%$ confidence limits $89.1-100 \%$ ).

The fasting $\mathrm{C}$-peptide concentration was correlated with the increase one hour after the meal in the 27 patients with a significant $\mathrm{C}$-peptide response to the meal $(\mathrm{r}=0.59 ; \mathrm{p}<0.001)$. The maximum increase in the C-peptide concentration following glucagon stimulation was significantly correlated with that after meal stimulation in the 32 patients who showed a significant $\mathrm{C}$-peptide response to glucagon ( $r=0.67 ; p<0.0001$ ) (Fig. 3). There was no significant difference in the average increase in plasma $\mathrm{C}$-peptide in response to the two tests.

\section{Discussion}

It has previously been shown that the increase in plasma C-peptide concentration in response to $1 \mathrm{mg}$ of IV glucagon is a quantitative measure of the functional B-cell secretory capacity under physiological conditions in patients with insulin-dependent diabetes of short duration [8]. The good correlation found in the present study between the C-peptide response to $1 \mathrm{mg}$ of IV glucagon and to a standard meal suggests that the glucagon test, as a measure of residual B-cell function, is applicable also to insulintreated diabetics with a diabetes duration of up to 50 years. Among the 64 patients examined with both tests, we found no false negative results of the glucagon test. On the other hand, the result was false positive in 5 patients, as the plasma C-peptide concentration increased significantly in response to glucagon, but did not show any significant increase in response to the standard meal. In these patients, however, the magnitude of the C-peptide response was very small. All patients with a C-peptide increase $>0.03 \mathrm{pmol} / \mathrm{ml}$ following glucagon had a significant response to the meal (Fig. 3). In the case of pronounced B-cell failure, glucagon thus seems to exert a greater stimulus to the B-cells than the test meal.

An evaluation of the discriminatory capacity of the glucagon test showed that the predictive value of a positive test was $84 \%$ and that of a negative test $100 \%$. The glucagon test, therefore, is probably applicable to measurements of the functional capacity of the B-cells during everyday life in diabetics on long-term insulin treatment.

Insulin-dependent diabetics were previously held to have an irreversible and absolute endogenous insulin deficiency. The $\mathrm{C}$-peptide concentration in plasma reported in insulin-treated patients with diabetes of short duration suggests, however, that residual B-cell function is retained in the majority of such patients $[4,5,6]$. The results from the present study show that residual B-cell function is present in most insulin-treated diabetics for the first five years of treatment. After that time, the prevalence of residual insulin secretion shows a marked fall. Among the diabetics with diabetes of more than 10 years' duration, few had any demonstrable insulin secretion (Fig. 1). In a recent study, Grajwer et al. [11] have reported a similar prevalence of functional B-cell survival in juvenile diabetes mellitus.

It has been suggested that the fasting $C$-peptide concentration is not only a qualitative, but also a quantitative measure of the insulin secretion [8]. This suggestion is supported by the present study, as the fasting $\mathrm{C}$-peptide concentration correlated well with the increase following stimulation. Only 2 of 43 patients with undetectable amounts of C-peptide in fasting plasma had a significant increase following stimulation with glucagon.

On the other hand, 6 patients with measurable amounts of C-peptide in fasting plasma showed no response to glucagon. A possible explanation is an extraordinarily high or low blood glucose level during the glucagon test. However, this was not the case. Elevated concentrations of C-peptide have been found in patients with reduced clearance of Cpeptide owing to impaired renal function [12]. In such patients, even an almost failing insulin secretion may be enough for C-peptide to be present at a low concentration. Short-term B-cell stimulation would not be expected to induce a significant increase in plasma $\mathrm{C}$-peptide concentration. However, none of the 6 patients without response to glucagon had a reduced renal function.

Cross-reaction of human proinsulin in the Cpeptide assay might also explain the missing C-peptide response to glucagon in patients with measurable fasting C-peptide concentrations. However, human proinsulin cross-reacts only to a small degree in the assay employed. It can thus be supposed that the patients in question had a modest insulin secretion, but that their B-cells were not responsive to glucagon.

The fasting C-peptide concentration therefore seems to be not only a qualitative, but also a quantitative measure of B-cell secretory capacity under physiologic conditions. All patients with a fasting Cpeptide concentration above $0.07 \mathrm{pmol} / \mathrm{ml}$ will have retained some functioning B-cells, and nearly all will respond to food with an increased insulin secretion. Patients with a fasting C-peptide concentration below $0.04 \mathrm{pmol} / \mathrm{ml}$ will have an absolute B-cell 
failure, whereas the B-cell function cannot be evaluated with certainty from the fasting C-peptide concentration alone in patients with fasting C-peptide concentrations between these values (Table 1).

The metabolic importance of an endogenous insulin production has been demonstrated in shortterm insulin-dependent diabetic subjects $[6,7]$. This finding is supported by the lower insulin requirement found in the group with residual B-cell function as compared to the group without any demonstrable B-cell function, the metabolic balance in the two groups being similar as judged by the fasting blood glucose concentration. Also in favour of this hypothesis is the finding that, among the patients with residual B-cell function, the insulin requirement was lowest in the patients with the highest B-cell secretory capacity evaluated from the fasting C-peptide concentration (Fig. 2).

Acknowledgements. We thank Miss Bodil Mathiassen and Miss Jane Falk for technical help. The English version was revised by Ilona Munck.

\section{References}

1. Melani, F., Rubenstein, A.H., Oyer, P., Steiner, D. F.: Identification of proinsulin and C-peptide in human serum by a specific immunoassay. Proc. Natl. Acad. Sci. USA 67, 148-155 (1970)

2. Horwitz, D. L., Starr, J.L., Mako, M.E., Blackard, W.G., Rubenstein, A.H.: Proinsulin, insulin, and C-peptide concentrations in human portal and peripheral blood. J. Clin. Invest. 55, 1278-1283 (1975)
3. Heding, L.G.: Radioimmunological determination of human C-peptide in serum. Diabetologia 11, 541-548 (1975)

4. Beischer, W., Heinze, E., Keller, L., Raptis, S., Kerner, W., Pfeiffer, E. F.: Human C-peptide. Part II: Clinical studies. Klin. Wochenschr. 54, 717-725 (1976)

5. Ludvigsson, J., Heding, L. G.: C-peptide in children with juvenile diabetes. Diabetologia 12, 627-630 (1976)

6. Faber, O.K., Binder, C.: B-cell function and blood glucose control in insulin dependent diabetics within the first month of insulin treatment. Diabetologia 13, 263-268 (1977)

7. Faber, O.K., Binder, C.: Plasma C-peptide during the first year of insulin dependent diabetes mellitus. Proceedings of the 9th IDF Congress 1977 , Excerpta Medica (in press)

8. Faber, O.K, Binder, C.: C-peptide response to glucagon: A test for the residual B-cell function in diabetes mellitus. Diabetes 26, 605-610 (1977)

9. Natvig, H.: Nye Høide - vekttabeller for norske kvinner og menn. Oslo: Landsforeningen for kosthold og helse 1956

10. Faber, O. K., Markussen, J., Naithani, V. K., Binder, C.: Production of antisera to synthetic benzyloxycarbonyl-C-peptide of human proinsulin. Hoppe Seylers Z. Physiol. Chem. 357, $751-757$ (1976)

11. Grajwer, L.A., Pildes, R.S., Horwitz, D.L., Rubenstein, A.H.: Control of juvenile diabetes mellitus and its relationship to endogenous insulin secretion as measured by C-peptide immunoreactivity. I. Pediatr. 90, 42-48 (1977)

12. Regeur, L., Binder, C.: The correlation between plasma Cpeptide and kidney function. Diabetologia 12, 416 (1976)

Recetved: Aprl 20, 1977, and in revised form: July 1, 1977

Dr. O. K. Faber

Hvidøre Hospital

Emiliekildevej 1

DK-2930 Klampenborg

Denmark 